\title{
Administering probiotic yakult + tape yeast into the mixture of rice and corn bran as partial replacement of commercial diet affects the carcass yield of broiler chickens
}

\author{
Zulfan*, Herawati Latif, Muhammad Aman Yaman, \\ Cut Aida Fitri, and Muhammad Haris Munandar \\ Animal Husbandry Department, Faculty of Agriculture, Syiah Kuala University, \\ Banda Aceh 23111, Indonesia
}

Submitted: 03 April 2020, Accepted: 05 March 2021

\begin{abstract}
The residue originated from antibiotics and hormones had been thought to carry out adverse effects for the human who consume meat processed from the broilers treated by antibiotic feed additive. For this reason, using an alternative additive such as probiotic might produce healthier meat. The objective of the recent study was to evaluate administering different levels of probiotic yakult + tape yeast (YTy) into the mixing of rice bran + corn bran (RCB) to replace $30 \%$ of the commercial diet to carcass yield and abdominal fat of broilers. As many as 100 broiler chicks, Cobb strain, were reared up to 5 weeks in this study. The study was designed into a Completely Randomized Design with subsampling consisted of 5 treatments, 4 replications, and 2 sub samples. Broiler commercial diet with the market code of CP 511 Hi-provite manufactured by PT Charoen Pokphand was used for a positive control diet $\left(\mathrm{P}_{0+}\right)$. The RCB feeds were mixed with $0,10,20$, and $30 \mathrm{ml} / \mathrm{kg}$ of probiotic YTy then being used to replace $30 \%$ of the commercial diet to build experimental diets $\mathrm{P}_{0-}, \mathrm{P}_{1}, \mathrm{P}_{2}$, and $\mathrm{P}_{3}$, respectively. The results of the recent study indicated that administering $10-30 \mathrm{ml} / \mathrm{kg}$ of probiotic YTy highly significantly $(\mathrm{P}<0.01)$ increased the weights of the whole carcass and carcass parts. The percentages of whole carcasses among $\mathrm{P}_{1}, \mathrm{P}_{2}$, and $\mathrm{P}_{3}$, however, were not statistically different. The percentage of the breast significantly $(\mathrm{P}<0.05)$ increased while the percentage of the back significantly $(\mathrm{P}<0.05)$ decreased. Although statistically not significant differences, the abdominal fat percentage tended to decline. In conclusion, administering a probiotic YTy in the diet increased the percentage of the whole carcass and tended to reduce the abdominal fat of the broiler.
\end{abstract}

Keywords: Probiotic; Yakult; Tape yeast; Broiler; Carcass

*Corresponding Author: zulfan_pet@yahoo.co.id 


\section{INTRODUCTION}

Broiler industries aim to produce meat with high carcass quality. The carcass quality is influenced by pre-slaughter as well, for example, employing antibiotics and hormones in the diet. The residue originated from antibiotics and hormones have been thought to carry out adverse effects for the human who consumes the processed meat. For this reason, using an alternative feed additive such as probiotic might result in healthier meat.

Probiotic is defined as a mixed culture of live microorganisms when applied to animals; beneficially affect the host by improving the properties of the indigenous microbiota (Jadhav et al., 2015). In animal husbandry, probiotic is utilized to improve feed quality. Probiotic contains various microorganisms of which Lactobacillus is extensively used in animal feed. Lactobacillus could stimulate the growth of natural Lactobacillus existing in the host animal's intestine, restrains the growth of pathogen microorganisms such as Escherichia coli, thus resulting in better feed efficiency and increasing body weight gain. Lactobacillus also improves the appetite of the host, constitutes the stability for intestinal microflora, stimulates the synthesis of vitamins, and builds immune response. One of the Lactobacillus species is Lactobacillus casei which is the probiotic in yakult, a probiotic commercial product (Widiyaningsih, 2011). O'Connel et al. (2010) found that Lactobacillus casei Shirota $(L c S)$ in yakult could induce an increased salivary IFN-g, $\operatorname{IgA}$, IgA1, and $\operatorname{IgA} 2$ secretion in healthy adults, which may improve mucosal immunity in the upper respiratory tract and provides health-related benefits.

Another microorganism often employed as a probiotic in the diet is Saccharomyces cerevisiae, the fungus. This species has immunostimulant activity improves the body's immune system, protects the body from disease infection from bacteria and virus. Saccharomyces is one of the microbes available in tape yeast.
Mandey et al. (2017) studied the use of tape yeast in fermenting pineapple waste meal and given to broiler resulting in better carcass quality and low abdominal fat percentage. Mulatu et al. (2019) used baker's yeast as a feed additive, which can be included in up to $2.5 \%$ of the total diet and improve the overall performance of broilers without compromising the hematological indices of broiler chickens.

The combination of both products would serve both microorganisms expectedly resulting in a more superior probiotic. Kumprecht et al. (1994) created the combination of Saccharomyces cerevisiae + Treptococcus faecum supplemented in broiler diet causing the reduction of the number of Escherichia coli up to $50 \%$ within the caecum, hence increased body weight of broiler. Based on this reason, it was attempted to use a probiotic produced by the combination of yakult and tape yeast (YTy) as an alternative feed additive.

This local probiotic was administered with different levels into feeds constituted of an equal amount of the mixing of rice bran + corn bran (RCB). The RCB added probiotic YTy then subsequently used to replace $30 \%$ of the commercial diet and then fed on the broilers for up to 5 weeks. The purpose of this research was to evaluate administering different levels of probiotic yakult + tape yeast into the mixing of rice bran + corn bran by replacing $30 \%$ of the commercial diet on carcass yields and abdominal fat of broilers.

\section{MATERIALS AND METHODS}

The research was conducted at the Field Laboratory of Animal Husbandry, Animal Husbandry Department, Syiah Kuala University from April 14 until May 12, 2019.

\section{Materials and equipment}

As many as 100 DOC of broilers, Cobb strain, were reared up to 5 weeks. Broiler commercial diet with the market code of CP 511 Hi-provite manufactured by PT Charoen Pokphand was used for a 
positive control diet. Rice bran and corn bran with an equal ratio were mixed to replace $30 \%$ of the commercial diet. The YTy was prepared by mixing the combination of an equal amount of yakult and tape yeast with coconut water, residual water of rice rinse, and molasses then sprayed to RCB. Other materials consisted of ND and IBD vaccines, vita chick, vita stress, and disinfectant. The equipment including 20 cages $1 \times 1 \mathrm{~m}$ as an experimental unit each, scales, heating bulbs, feeders, and drinkers were utilized to support the research.

\section{Treatments}

The treatment was administering probiotic based on the combination of $50 \%$ yakult $+50 \%$ tape yeast (YTy) with different doses in feed ingredients composed of $50 \%$ rice bran $+50 \%$ corn bran $(\mathrm{RCB})$. As many as $30 \%$ of this feed mixture containing probiotic YTy with the level of 10,15 , and $20 \mathrm{ml}$, respectively was mixed into the base diet which was commercial diet CP511. The nutrient contents of experimental diet were given in Table.

The treatments were as following:

$\mathrm{P} 0+=100 \%$ commercial diet CP511 (control+)

P0- $=70 \%$ commercial diet CP511 $+30 \%$ RCB (control-)

$\mathrm{P} 1=70 \%$ commercial diet $\mathrm{CP} 511+30 \%$ $\mathrm{RCB}+$ probiotic YTy $10 \mathrm{ml} / \mathrm{kg}$

$\mathrm{P} 2=70 \%$ commercial diet $\mathrm{CP} 511+30 \%$ $\mathrm{RCB}+$ probiotic YTy $15 \mathrm{ml} / \mathrm{kg}$

P3 $=70 \%$ commercial diet CP511 $+30 \%$ $\mathrm{RCB}+$ probiotic YTy $20 \mathrm{ml} / \mathrm{kg}$

Table 1. Composition and nutrient content of experimental diets



${ }_{1}^{1}$ Nutrient content refers to market label of commercial diet CP511

${ }^{2}$ Nutrient content refers to Hartadi et al. (2005)

\section{Experimental design}

The research was set up into a Completely Randomized Design with subsamplings consisting of 5 treatments, 4 replications, and 2 subsamples. Each replication was an experimental unit consisted of 5 birds each. The model for Completely Randomized Design with subsampling according to Steel and Torrie
(1993) was: $Y_{i j k}=\mu+\tau_{i}+\varepsilon_{i j}+d_{i j k}$ where $Y_{i j k}=$ observation value, $\mu=$ an overall mean, $\tau_{i}=$ an effect due to diet, $\varepsilon_{i j}=$ a sampling error, and $d_{i j k}=$ a subsampling error.

Research procedure

The procedure of this research was as follows (1) The preparation consisted of cage construction and diet formulation, (2) As many as 20 cages along with equipment 
were rinsed and disinfected then allowed for 2 weeks, (3) Each cage was set up by a 40watt bulb and scattered by $6 \mathrm{~cm}$ litter, (4) A feeder and drinker were placed into each cage, and, (5) Diet formulation was initially by mixing probiotic YTy with experimental diets. Growing the chicks was started from DOC until 5 weeks.

The birds were fed experimental diets of which composed of the basal diet of CP 511 ad libitum for overall periods. Drinking water was supplied ad libitum, vita chick was given during the first two weeks, and next vita stress during the rest weeks. The ND vaccine was offered on the third day and at the end of the third week while the IBD vaccine was given on day 10 . At the end of 5 weeks, all birds were weighed to record final body weight (FBW). Two birds with average body weight (BW) close to the average $\mathrm{BW}$ in each unit were slaughtered and eviscerated for carcass collection.

\section{Making probiotic YTy}

The procedure of mixing probiotic yakult + tape yeast was run by following the method of fermentation. Firstly, feed ingredients consisted of rice bran and corn bran were weighed equally then mixed and homogenized. The probiotic yakult + tape yeast was initially made up by mixing coconut water 1 liter + residual water of rice rinse 2 liters + molasses 0.5 liters. Afterward, both yakult 2 small bottles and tape yeast 2 tablets were included in the mixture resulted in so call probiotic YTy.

This probiotic then was sprayed into the RCB and inserted into the plastic bag. The bag containing the stuff was tied tightly to achieve as close as possible anaerobe condition. Furthermore, the bag was placed in a dark room under room temperature for 7 days.

\section{Parameters}

Parameters observed in this study were as follows:

1. Weight and percentage of the whole carcass: Carcass weight was obtained by weighing carcass after evisceration and removal out of noncarcass parts. The percentage of the carcass was determined by dividing carcass weight and live weight.

2. Weights and percentages of carcass parts: Weights of the carcass parts (breast, thighs, wings, and back) were obtained by weighing each part after separated from each tissue. The percentage of each part was determined by dividing each part's weight by whole carcass weight.

3. Weight and percentage of abdominal fat: Abdominal fat was obtained by weighing fat after pulled out of the abdominal cavity and viscera. The percentage of abdominal fat was determined by dividing abdominal weight by body weight.

\section{Data analysis}

Data were analyzed by Analysis of Variance (ANOVA). The analysis was continued by Duncan's Multiple Range Test (DMRT) with the procedure $\mathrm{W}_{\mathrm{r}}^{\prime}=$ $\mathrm{q}^{\prime} \alpha(\mathrm{r}, \mathrm{v}) \sqrt{\left(\mathrm{s}^{2} \mathrm{w} / \mathrm{n}^{\prime}\right)}$ as significant differences ( $F_{\text {obs. }}>\mathrm{F}_{\text {tab. } \alpha=0.05}$ ) were detected (Steel and Torrie, 1991).

\section{RESULT AND DISCUSSION Whole carcass}

Weights and percentages of whole carcasses of broiler fed the experimental diets were given in Table 3. The result of ANOVA indicated that administering probiotic YTy in the RCB highly significantly $(\mathrm{P}<0.01)$ affected on whole carcass weights of broiler chickens. Most of the carcass characteristics were directly proportional to the increased BW at the time of slaughter (Jadhav et al., 2015).

Replacing commercial diet with $30 \%$ of the RCB caused the increase of crude fiber $(\mathrm{CF})$ in high amounts from $4.00 \%\left(\mathrm{P}_{0+}\right)$ to $8.20 \%\left(\mathrm{P}_{0-}\right)$ (Table 2). Crude fiber (cellulose) was not well digested by the birds due to the absence of cellulosic enzyme. Bird consuming high $\mathrm{CF}$ might suffer ME deficiency causing the decline of body capacity to gain carcass. In the recent study, carcass weights had loosed approximately 50\% from $1.241\left(\mathrm{P}_{0+}\right)$ to 603 $\mathrm{kg}$ ( $\left.\mathrm{P}_{0-}\right)$. According to NRC (1994), the requirement of $\mathrm{ME}$ for a broiler was 3.000- 
$3.200 \mathrm{kcal} / \mathrm{kg}$. The levels of ME within the diet $\mathrm{P}_{0}$ - had reduced from $3.000 \mathrm{kcal} / \mathrm{kg}\left(\mathrm{P}_{0+}\right)$ to $2.765 \mathrm{kcal} / \mathrm{kg}\left(\mathrm{P}_{0}\right)$. The $\mathrm{ME}$ was the major component involved in the process of metabolism within the animal body (Parakkasi, 2002). A diet with a low density of ME leads to impeding the absorption of any nutrients in the body.

Table 3. Weights and percentages of whole carcasses of broilers

\begin{tabular}{lccccc}
\hline Body weights and & \multicolumn{5}{c}{ Experimental diets } \\
\cline { 2 - 5 } whole carcasses & $\mathrm{P}_{0+}$ & $\mathrm{P}_{0-}$ & $\mathrm{P}_{1}$ & $\mathrm{P}_{2}$ & $\mathrm{P}_{3}$ \\
\hline Body weights $(\mathrm{g})$ & $1.836 \pm 111^{\mathrm{c}}$ & $961 \pm 171^{\mathrm{a}}$ & $1.516 \pm 76^{\mathrm{b}}$ & $1.507 \pm 185^{\mathrm{b}}$ & $1.549 \pm 139^{\mathrm{b}}$ \\
Carcass weights $(\mathrm{g})$ & $1.241 \pm 75^{\mathrm{c}}$ & $603 \pm 118^{\mathrm{a}}$ & $1.046 \pm 64^{\mathrm{b}}$ & $1.041 \pm 101^{\mathrm{b}}$ & $1.029 \pm 106^{\mathrm{b}}$ \\
$(\%)$ & $67.80 \pm 3,41$ & $62.50 \pm 2.09$ & $69.09 \pm 4.05$ & $69.57 \pm 7.26$ & $66.97 \pm 9.63$ \\
\hline$a, b, c$ & The number in the same row with different & & & &
\end{tabular}

In addition to $\mathrm{ME}$, the protein was required by the birds for body maintenance, feather growth, and tissue development (Scott et al., 2000). Replacing commercial diet with $30 \%$ of the RCB also caused the decline of dietary $\mathrm{CP}$ from $21.00 \%\left(\mathrm{P}_{0+}\right)$ to $17.88 \%$ ( $\left.\mathrm{P}_{0-}\right)$. Deficiency protein inhibited tissue maintenance, body growth, and carcass production.

Administering a probiotic YTy at 10 $20 \mathrm{ml} / \mathrm{kg}$ into the RCB improved the quality of feed might be due to the increase of feed digestibility and bird health. Bidura et al. (2009) reported that the inclusion of fermentation tape yeast products in diets could increase nutrient digestibility and growth performance. Pourakbari et al. (2015) found probiotics in broiler feed at $0.01 \%$ or higher levels of supplementation increased $(\mathrm{P}<0.05) \quad$ Enterococci and decreased $(\mathrm{P}<0.05)$ Escherichia coli counts in the ceca and then improved BWG.

The result of the DMRT test indicated that the carcass weight of broilers fed the commercial diet of which $30 \%$ replaced with the RCB administered by the probiotic YTy $\left(\mathrm{P}_{1}-\mathrm{P}_{3}\right)$ highly significantly $(\mathrm{P}<0.01)$ increased the whole carcass compared to those fed the RCB with the absence of probiotic YTy ( $\left.\mathrm{P}_{0-}\right)$. Agree to Kabir (2009), probiotics could be successfully used as nutritional tools in poultry feeds for promotion of growth, modulation of intestinal microflora and pathogenic inhibition, immunomodulation, and promoting meat quality of poultry. It seems probiotic YTy was able to recover carcass yield in a limited capacity since the achievement of carcass weight was still less than $\mathrm{P}_{0+}$. A high amount of RCB replacing commercial diet, therefore, caused a severe nutrient imbalance. Based on percentage, although statistically no significant differences were detected, broilers fed the commercial diet of which $30 \%$ replaced with the RCB administered by the probiotic YTy $\left(\mathrm{P}_{1}-\mathrm{P}_{3}\right)$ were liable to gain the percentage of carcass higher than those fed the RCB with the absence of probiotic $\left(\mathrm{P}_{0-}\right)$ even $\mathrm{P}_{1}$ and $\mathrm{P}_{2}$ were higher than $\mathrm{P}_{0+}$. Probiotic YTy was considered to play role in increasing carcass weight and percentage. As reported by Paryad and Mahmoudi (2008), dietary S. cerevisiae could improve the performance, blood constituents, and carcass characteristics of broilers.

Cellulolytic enzymes released by the microorganisms could act as a useful additive in the diet. Probiotic YTy contained Lactobacillus casei originated from yakult and fungi Saccharomyces cerevisiae from yeast. Lactobacillus released cellulosic aiding in the digestive process. This enzyme was able in breaking down CF to any simple components easily absorbed by the birds in their digestive tracts to support tissue growth and body weight gain (McNaught and MacFie, 2000). Moreover, probiotic microbes secreted antimicrobial products such as bacteriocin to retard the growth of pathogenic microorganisms. Within the intestinal tract, Lactobacillus released several digestive enzymes, for instance, lactase to make use 
of indigestible carbohydrates, stimulate volatile fatty acids, and produce antibacterial compounds (Nahashon, 1996). These compounds were capable to depress pathogenic bacterial growth allowing the nonpathogenic bacteria to highly develop in the epitel intestine and support to enrich the absorption of numerous nutrients (Kvan et al., 2017). Based on DMRT, administering probiotic YTy at the levels of 10, 15, and 20 $\mathrm{ml} / \mathrm{kg}\left(\mathrm{P}_{1}-\mathrm{P}_{3}\right)$ did not show any differences in the weight and percentage of the carcass. It means administering probiotic YTy at 10 $20 \mathrm{ml} / \mathrm{kg}$ resulted in a similar effect to produce broiler carcasses. The same results had been reported by Ronstarci et al. (2013), adding probiotics in different doses in the diet did not significantly affect carcass percentage. The live weights and carcass percentages were illustrated in Fig. 1.

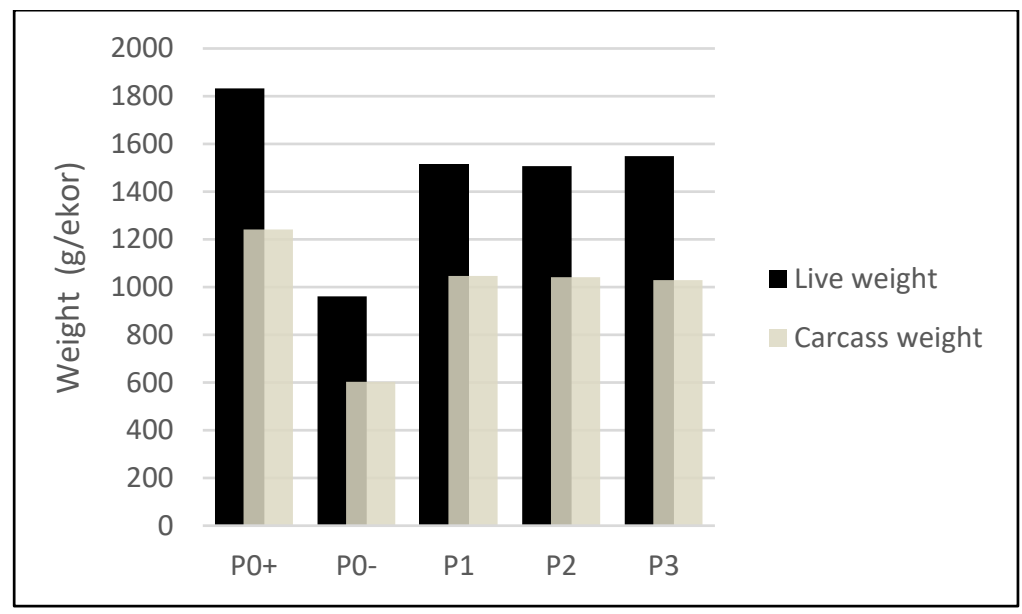

Figure 1. Body weight and carcass percentage of broilers

\section{Carcass parts}

Weights and percentages of carcass parts of broilers fed the experimental diets were given in Table 4 . The results of ANOVA indicated that administering probiotic YTy in the RCB highly significantly $(\mathrm{P}<0.01)$ affected the weights of all carcass parts. These parts draw a parallel with the whole carcass weight. According to Soeparno (2009), the weight of carcass parts correlated to the weight of the whole carcass.

As a percentage, a highly significant difference was detected on the percentages of chicken backs for which birds fed the $\mathrm{P}_{0}$ had higher back percentages than those fed $\mathrm{P}_{0+}$. The back was supposed of having low economic value. Diminishing protein and ME content as well as increasing $\mathrm{CF}$ in the diet as a result of replacing $30 \%$ of the commercial diet with the RCB affected an optimal tissue composition. Hence, birds fed $\mathrm{P}_{0-}$ and $\mathrm{P}_{1}-\mathrm{P}_{3}$ produced breasts significantly lower $(\mathrm{P}<0.05)$ than they fed $\mathrm{P}_{0+}, \quad$ while the percentages of thighs and wings were not significantly different. Administering a probiotic YTy represented a positive effect on the percentages of carcass parts. The percentage of back highly significantly $(\mathrm{P}<0.01)$ declined, while breast significantly $(\mathrm{P}<0.05)$ inclined on broilers fed $\mathrm{P}_{1}-\mathrm{P}_{3}$ compared to $\mathrm{P}_{0}$. Agree to the report of Khaksefidi and Rahimi (2005), the leg and breast meat of chickens fed diets containing probiotics were higher $(\mathrm{p}<0.05)$ compared to control chickens. Based on Candrasih and Bidura (2001), using a probiotic in the diet was able to enhance protein retention playing important role in the formation of muscle tissue. However, the different levels of probiotic YTy did not significantly influence meaning administering 10 or $20 \mathrm{ml} / \mathrm{kg}$ probiotic YTy presented relatively equal results.

\section{Noncarcass}

Parts of noncarcass observed in this research were head, shank, and abdominal fat. Weights and percentages of these organs of broilers fed the experimental diets were given in Table 5 . 
The results of ANOVA indicated that administering probiotic YTy in the RCB highly significantly $(\mathrm{P}<0.01)$ affected weights of head and shanks of broilers. It is associated with body weight as reported by Soeparno (2009), weights of body chicken parts correlated to their live weight. The higher the live weight the higher body part weights. As a percentage, no significant difference was detected on the percentage of the head, but the percentage of shanks was highly significantly $(\mathrm{P}<0.01)$ affected. Replacing commercial diet with $30 \%$ of the
$\mathrm{RCB}\left(\mathrm{P}_{0-}\right)$ highly significantly increased the proportion of noncarcass which was shanks. This result indicated that feeding broilers with the commercial diet of which $30 \%$ replaced with the RCB caused the birds to suffer-malnutrition. Administering probiotic YTy to the RCB for replacement $30 \%$ of the commercial diet $\left(\mathrm{P}_{1}-\mathrm{P}_{3}\right)$ aided to improve the quality of the feed then reduce shank proportions. Despite this, the percentages of shanks of the broilers from all treatments were in the range of $3,62-4,78 \%$ close to reported by Jull (1992) i.e. $4.40 \%$.

Table 4. Weights and percentages of carcass parts

\begin{tabular}{ccccccc}
\hline \multirow{2}{*}{ Carcass parts } & \multicolumn{5}{c}{ Experimental diets } \\
\cline { 3 - 7 } & & $\mathrm{P}_{0+}$ & $\mathrm{P}_{0-}$ & $\mathrm{P}_{1}$ & $\mathrm{P}_{2}$ & $\mathrm{P}_{3}$ \\
\hline \multirow{2}{*}{ Breast } & $(\mathrm{g})$ & $454.4 \pm 38.1^{\mathrm{c}}$ & $196.1 \pm 43.6^{\mathrm{a}}$ & $359.6 \pm 27.5^{\mathrm{b}}$ & $363.5 \pm 31.8^{\mathrm{b}}$ & $356.6 \pm 34.9^{\mathrm{b}}$ \\
& $(\%)$ & $36.56 \pm 0.98^{\mathrm{C}}$ & $32.40 \pm 2.40^{\mathrm{A}}$ & $34.35 \pm 0.86^{\mathrm{B}}$ & $35.02 \pm 2.18^{\mathrm{B}}$ & $34.70 \pm 1.43^{\mathrm{B}}$ \\
Thighs & $(\mathrm{g})$ & $388.0 \pm 13.9^{\mathrm{c}}$ & $192.0 \pm 39.3^{\mathrm{a}}$ & $336.4 \pm 18.6^{\mathrm{b}}$ & $338.0 \pm 23.7^{\mathrm{b}}$ & $334.0 \pm 26.2^{\mathrm{b}}$ \\
& $(\%)$ & $31.31 \pm 0.89$ & $31.85 \pm 1.42$ & $32.16 \pm 0.34$ & $32.58 \pm 1.58$ & $32.54 \pm 1.11$ \\
Wings & $(\mathrm{g})$ & $152.6 \pm 10.3^{\mathrm{c}}$ & $60.6 \pm 9.7^{\mathrm{a}}$ & $115.5 \pm 17.7^{\mathrm{b}}$ & $114.8 \pm 17.8^{\mathrm{b}}$ & $111.3 \pm 23.2^{\mathrm{b}}$ \\
& $(\%)$ & $12.29 \pm 0.17$ & $10.23 \pm 1.44$ & $10.99 \pm 1.07$ & $10.94 \pm 1.21$ & $10.72 \pm 1.20$ \\
Back & $(\mathrm{g})$ & $246.1 \pm 17.5^{\mathrm{Cb}}$ & $153.9 \pm 30.9^{\mathrm{Aa}}$ & $234.9 \pm 10.7^{\mathrm{BCb}}$ & $224.6 \pm 45.8^{\mathrm{BCb}}$ & $227.4 \pm 33.2^{\mathrm{BCb}}$ \\
& $(\%)$ & $19.84 \pm 0.93^{\mathrm{a}}$ & $25.52 \pm 0.89^{\mathrm{c}}$ & $22.50 \pm 1.37^{\mathrm{b}}$ & $21.45 \pm 3.67^{\mathrm{b}}$ & $22.05 \pm 2.14^{\mathrm{b}}$ \\
\hline
\end{tabular}

${ }_{A, B, C}$ The number in the same row with different superscripts indicated significant differences $(\mathrm{P}<0.05)$

$a, b, c$ The number in the same row with different superscripts indicated highly significant differences $(\mathrm{P}<0.01)$

Table 5. Weights and percentages of noncarcass of broilers

\begin{tabular}{ccccccc}
\hline \multirow{2}{*}{ Noncarcass } & & \multicolumn{5}{c}{ Experimental diets } \\
\cline { 3 - 6 } & & $\mathrm{P}_{0+}$ & $\mathrm{P}_{0-}$ & $\mathrm{P}_{1}$ & $\mathrm{P}_{2}$ & $\mathrm{P}_{3}$ \\
\hline \multirow{2}{*}{ Head } & $(\mathrm{g})$ & $76.1 \pm 8.6^{\mathrm{d}}$ & $37.5 \pm 4.2^{\mathrm{a}}$ & $62.3 \pm 8.8^{\mathrm{c}}$ & $50.3 \pm 12.9^{\mathrm{b}}$ & $65.8 \pm 11.0^{\mathrm{c}}$ \\
& $(\%)$ & $4.15 \pm 0.32$ & $3.96 \pm 0.40$ & $4.13 \pm 0.73$ & $3.34 \pm 0.79$ & $4.25 \pm 0.63$ \\
Shank & $(\mathrm{g})$ & $66.1 \pm 4.0^{\mathrm{Cd}}$ & $45.5 \pm 7.1^{\mathrm{a}}$ & $63.9 \pm 10.4^{\mathrm{Ccd}}$ & $55.3 \pm 10.9^{\mathrm{Bb}}$ & $57.8 \pm 9.7^{\mathrm{Bbc}}$ \\
& $(\%)$ & $3.62 \pm 0.26^{\mathrm{a}}$ & $4.78 \pm 0.50^{\mathrm{c}}$ & $4.24 \pm 0.85^{\mathrm{b}}$ & $3.68 \pm 0.68^{\mathrm{a}}$ & $3.77 \pm 0.81^{\mathrm{a}}$ \\
\multirow{2}{*}{ Abdominal fat } & $(\mathrm{g})$ & $20.4 \pm 5.3$ & $12.4 \pm 4.2$ & $19.5 \pm 6.7$ & $17.4 \pm 8.3$ & $15.3 \pm 7.5$ \\
& $(\%)$ & $1.12 \pm 0.31$ & $1.29 \pm 0.46$ & $1.29 \pm 0.45$ & $1.17 \pm 0.54$ & $0.98 \pm 0.47$ \\
\hline
\end{tabular}

$\overline{A, B, C}$ The number in the same row with different superscripts indicated significant differences $(\mathrm{P}<0.05)$

$a, b, c, d$ The number in the same row with different superscripts indicated highly significant differences $(\mathrm{P}<0.01)$

\section{Abdominal fat}

The results of ANOVA indicated that administering a probiotic YTy in the RCB did not significantly affect weight and percentage of abdominal fat. Nerveless, improper dietary nutrients particularly dietary $\mathrm{CP}$ in the commercial diet undergoing $30 \%$ replacement with the RCB
$\left(\mathrm{P}_{0-}\right)$ tended to increase the percentage of abdominal fat.

The birds were not able to utilize the available nutrients to perform an excellent carcass. As reported by Chrystal et al. (2020), the reduction in CP from 200 to 156 $\mathrm{g} / \mathrm{kg}$ increased relative fat-pad weights by $69.9 \%$. Administering $15-20 \mathrm{ml} / \mathrm{kg}$ of 
probiotic YTy to the RCB $\left(\mathrm{P}_{1}-\mathrm{P}_{3}\right)$ provided a positive impact to restrain abdominal fat deposit. Probiotic YTy was considered to be capable to generate a proper fat deposit. Agree to Miazzo et al. (2005), the chickens fed yeast ( $S$. cerevisiae) accumulated significantly $(\mathrm{p} \leq 0.05) 12 \%$ and $15 \%$ less fat abdominal weight than those fed without yeast.

The same result was also reported by Daud et al. (2007), the inclusion of the probiotic into the broiler ration could reduce fat. Probiotic YTy contained microorganisms of Lactobacillus casei that could convert glucose into lactic acid (Kònig et al., 2013) inhibits glycolysis, subsequently diminishes triglyceride and asetil KoA. As a result, the biosynthesis of body lipid including abdominal fat declined. The mechanism of Lactobacillus casei of releasing lactic acid caused the environmental area in the small intestine to become in the condition of relatively acid with lower $\mathrm{pH}$. In lower $\mathrm{pH}$, the process of fat digestion might run slowly so that fat was limitedly absorbed.

Yet, the percentages of abdominal fat of broilers from all treatments were in the range of $0,98-1,29 \%$ close to reported by Leeson and Summers (2005) i.e. 1-2,5\%. Therefore, low abdominal fat was an advantage due to a better carcass quality (Sanz et al., 2000).

\section{CONCLUSIONS}

Based on the results of this study, it was concluded that administering a probiotic constituted by the combination of yakult + tape yeast (YTy) increased the carcass yield of broiler chicken. Probiotic YTy increased the percentages of valuable parts of carcass such as breast, thighs, and wings but abdominal fat tended to reduce. It was suggested that to reduce the levels by less than $30 \%$ of the mixing of rice bran + corn bran with the presence of yakult + tape yeast as local probiotic replacing the partial number of the commercial diet to reach an optimal final body weight of broilers for generating economic benefits.

\section{REFERENCES}

Ameha, N., Girma, M., \& Mulatu, K. (2019). Effects of feeding different levels of baker s yeast on performance and hematological parameters in broiler chickens. Journal of World's Poultry Research, 9(2), 38-49. https://doi.org/10.36380/jwpr.2019.5

Bidura, I. G. N., Warmadewi, D. A., Candrawati, D. P. M. A., Aryani, I. G. A. I., Utami, I. A. P., Partama, I. B., \& Astuti, D. A. (2009). The effect of ragi tape fermentation products in diets on nutrients digestibility and growth performance of bali drake. The 1st International Seminar on Animal Industry, 180-187.

Candrasih, N. N., \& Bidura, I. G. N. G. (2001). Pengaruh penggunaan cangkang kakao yang disuplementasi ragi tape dalam ransum terhadap penampilan itik bali. Majalah Ilmiah Peternakan, 4(3), 67-72.

Chrystal, P. V., Moss, A. F., Khoddami, A., Naranjo, V. D., Selle, P. H., \& Liu, S. Y. (2020). Effects of reduced crude protein levels, dietary electrolyte balance, and energy density on the performance of broiler chickens offered maize-based diets with evaluations of starch, protein, and amino acid metabolism. Poultry Science, 99(3), 1421-1431. https://doi .org/10.1016/j.psj.2019.10.060

Daud, M., Piliang, W, G., \& Kompiang, I. P. (2006). Persentase dan kualitas karkas ayam pedaging yang diberi probiotik dan prebiotik dalam ransum. Indonesian Journal of Animal and Veterinary Sciences, 6(2), 126-131.

Hartadi, H., Reksohadiprodjo, S., \& Tillman, A. D. (2005). Komposisi Bahan Pakan untuk Indonesia. Gadjah Mada University Press.

Jadhav, K., Sharma, K. S., Katoch, S., Sharma, V., \& Mane, B. G. (2015). Probiotics in broiler poultry feeds: a review. Journal of Animal Nutrition and Physiology, 1, 4-16.

Jull, M. (1992). Poultry Husbandry (3rd 
ed.). Mc Graw Hill Publishing Company.

Kabir, S. M. L. (2009). The role of probiotics in the poultry industry. International Journal of Molecular Sciences, 10(8), 3531-3546. https:// doi.org/10.3390/ijms 10083531

Khaksefidi, A., \& Rahimi, S. (2005). Effect of probiotic inclusion in the diet of broiler chickens on performance, feed efficiency and carcass quality. AsianAustralasian Journal of Animal Sciences, 18(8), 1153-1156. https:// doi.org/10.5713/ajas.2005.1153

Kumprecht, I., Zobac, P., Gasnarek, Z., \& Robosova, E. (1994). The effect of continuous applications of probiotics preparations based on S. cerevisiae var elipsoideus and Streptococcus faecium C-68 (SF-68) on chicken broiler yield. Zivocisma-Yroba, 39(6), 491-503.

Kvan, O. V., Gavrish, I. A., Lebedev, S. V., Korotkova, A. M., Miroshnikova, E. P., Serdaeva, V. A., Bykov, A. V., \& Davydova, N. O. (2018). Effect of probiotics on the basis of Bacillus subtilis and Bifidobacterium longum on the biochemical parameters of the animal organism. Environmental Science and Pollution Research, 25(3), 2175-2183. https://doi.org/10. 1007/s11356-017-0534-9

Kônig, H., Unden, G., \& Fröhlich, J. (2013). Biology of Microorganisms on Grapes, in Must and in Wine (2nd ed.). Springer-International Publishing.

Leeson, S., \& Summers, J. D. (2005). Commercial Poultry Nutrition (3rd ed.). University Books.

Mandey, J. S., Tulung, B., Leke, J. R., \& Sondakh, B. F. J. (2018). Performance and carcass quality of broiler chickens fed diet containing pineapple waste meal fermented by "ragi tape." IOP Conference Series: Earth and Environmental Science, 102, 012042. https://doi.org/10.1088/1755-1315/10 2/1/012042

McNaught, C., \& MacFie, J. (2001).
Probiotics in clinical practice: a critical review of the evidence. Nutrition Research, 21(1-2), 343353. https://doi.org/10.1016/S02715317(00)00286-4

Miazzo, R. D., Peralta, M. F., Picco, M. L., \& Nilson, A. J. (2005). Productive parameters and carcass quality of broiler chickens fed yeast ( $\mathrm{S}$. cerevisiae). XVII Th European Symposium on the Quality of Poultry Meat Doorwerth, The Netherlands, May, 2004-2006.

Nahashon, S. (1996). Animal Feed Science Technology. Elsevier.

NRC. (1994). Nutrient Requirement of Poultry. In National Research Council (9th ed.). National Academy Press.

O’Connel, E., Allgrove, J., Pollard, L., Xiang, M., \& Harbige, L. S. (2010). A pilot study investigating the effects of yakult fermented milk drink (L. casei Shirota) on salivary IFN-g, sIgA, IgA1 and IgA2 in healthy volunteers. Proceedings of the Nutrition Society, 69.

Parakkasi, A. (2002). Ilmu Gizi dan Makanan Ternak Monogastrik (1st ed.). Penerbit Angkasa.

Paryad, A., \& Mahmoudi, M. (3 C.E.). Effect of different levels of supplemental yeast (Saccharomyces cerevisiae) on performance, blood constituents, and carcass characteristics of broiler chicks. African Journal of Agricultural Research, 12(835-842).

Pourakbari, M., Seidavi, A., Asadpour, L., \& Martínez, A. (2016). Probiotic level effects on growth performance, carcass traits, blood parameters, cecal microbiota, and immune response of broilers. Anais Da Academia Brasileira de Ciências, 88(2), 10111021. https://doi.org/10.1590/00013765201620150071

Ronstarci, T., Osfar, S., \& Irfan, H. D. (2013). Pengaruh Penambahan Probiotik Selulolitik (Cellulomonas sp.) Dalam Pakan Terhadap Kualitas Karkas, Lemak Abdominal Dan Berat 
Organ Dalam Ayam Pedaging. Universitas Brawijaya.

Sanz, M., Lopez-Bote, C. J., Flores, A., \& Carmona, J. M. (2000). Effect of the inclusion time of dietary saturated and unsaturated fats before slaughter on the accumulation and composition of abdominal fat in female broiler chickens. Poultry Science, 79(9), 1320-1325. https://doi.org/10.1093/ ps/79.9.1320

Scott, M., Nesheim, M. C., \& Young, R. J.
(2000). Nutritions of the Chickens. ML Scott and Associates.

Soeparno. (2009). Ilmu dan Teknologi Daging. Gadjah Mada University Press.

Steel, R. G. D., \& Torrie, J. H. (1991). Prinsip dan Prosedur Statistika (B. Sumantri (ed.)). PT Gramedia.

Widiyaningsih, E. N. (2011). Peran probiotik untuk kesehatan. Jurnal Kesehatan, 4(1), 14-20. 